\title{
Aklime edilmiş aktif çamur mikroorganizmaları ile sürekli sistem yukarı akışı dolgulu kolonda 2,4- diklorofenol gideriminin incelenmesi
}

\section{Investigation of 2,4- dichlorophenol removal in continuous system upflow filled column with activated sludge microorganisms}

\author{
Ece Ümmü Deveci ${ }^{1}$,* \\ ${ }^{1}$ Niğde Ömer Halisdemir Üniversitesi, Mühendislik Fakültesi, Çevre Mühendisliği Bölümü, 51240, Niğde Türkiye
}

\begin{abstract}
Özet
Endüstriyel üretim sonrası ortaya çıkan atıksular alıcı ortamlara verilmeden önce atıksu içeriğinde bulunan kirlilik parametrelerinin deşarj kriterlerin altında arıtılması gerekmektedir. Fenol ve türevi olan kimyasal bileşikler endüstriyel üretim sonrası atıksular içerisinde yüksek konsantrasyonda bulunmaktadırlar. $\mathrm{Bu}$ fenol ve türevi bileşikleri içeren atıksular kanserojenik ve teratojenik etkilere sahiptir. $\mathrm{Bu}$ nedenle bu tip atıksuların alıcı ortamlara arıtılmadan deşarj edilmemesi gerekmektedir. Bu amaçla bu çalışmada 2,4- diklorofenol ile aklime edilmiş aktif çamur mikroorganizmalarının yukarı akışlı olarak poliüretan ile doldurulmuş kolonda 2,4- diklorofenol giderimi incelenmiştir. Aklime edilmiş aktif çamur mikroorganizmaları poliüretan sünger parçaları üzerine immobilize edilmiş ve yukarı akışlı dolgulu kolonda 2,4dikolorofenolün sürekli sistemde 90 gün boyunca arıtımı incelenmiştir. Elde edilen sonuçlara göre en optimum 500 mg/L 2,4-dikolorofenol komsatrasyonunda \%83 KOİ ve $\% 86$ fenol giderimi sağlanmıştır.
\end{abstract}

Anahtar kelimeler: 2,4-DKF, Aklimasyon, İmmobilizasyon, Yukarı akışlı dolgulu kolon, Mikro gözenekli poliüretan

\section{Giriş}

Doğaya verilen ksenobiyotik özellikli organik kimyasallar genel olarak uzun zincirli alkilfenoller ve klorofenoller; evlerde, ticari ve endüstriyel uygulamalarda yaygın olarak kullanılmaktadır [1,2]. Bu hammaddeler, alıcı ortamlara karıştığında mikro kirleticiler olarak değerlendirilmekte olup son zamanlarda daha dikkat çekici hale gelmiştir [3]. Genel olarak endüstriyel olarak ortaya çıkan fenol ve türevleri; tekstil, ilaç, plastik, kâğıt ve boya, tarım ilaçları ve dezenfektan maddelerin üretiminde kullanılmaktadır [4]. Klorofenoller ise genel olarak pestisit üretiminde ve klorlu hidrokarbonların bozulmasıyla ortaya çıkan toksik bir bileşiktir [5]. Klorofenoller çok düşük konsantrasyonlarda dahi suda tat ve koku problemi oluşturmaktadır. Ayrıca mikrokirletici olarak sularda bulunduklarında suda yaşayan canlılar ve insanlar için yüksek toksisite ve biyolojik birikime sahiptir $[1,6,7]$. Bu

\begin{abstract}
The pollution parameters in the wastewater must be treated below the discharge criteria before the wastewater generated after industrial production is discharged to the receiving environment. Phenol and its derivatives are found in high concentrations in wastewater after industrial production. Wastewater containing this phenol and its derivatives have carcinogenic and teratogenic effects. Therefore, this type of wastewater should not be discharged to receiving environments without treatment. For this purpose, in this study, the removal of 2,4-dichlorophenol in a column filled with polyurethane upstream of activated sludge microorganisms activated with 2,4-dichlorophenol was investigated. Activated sludge microorganisms were immobilized on polyurethane sponge pieces and the purification of 2,4-dichlorophenol in a continuous system for 90 days in an upstream filled column was studied. According to the results, 83\% COD and 86\% phenol removal was achieved at the optimum $500 \mathrm{mg} / \mathrm{L} \mathrm{2,4-}$ dichlorophenol compensation.
\end{abstract}

Keywords: 2,4- Dichlorophenol, Acclimation, İmmobilization, Upstream filled column, Microporous polyurethane

gibi olumsuz etkileri nedeniyle Dünya Sağlık Örgütü (WHO) tarafindan fenol konsantrasyonu içme sularında $1 \mathrm{mg} / \mathrm{L}$ olarak sınırlandırılmıştır [8]. WHO tarafından yüzey suyu, atık su, yeraltı suyu ve içme suyunda klorofenollerin dünya çapında tespit edilerek izlenmiştir. Elde edilen veriler değerlendirilerek insan sağlı̆̆ çıkabilecek potansiyel tehlikeler belirlenmiştir [9]. Klorofenollerin biyolojik parçalanması ile ilgili olarak fungus ve bakterilerin kullanıldığı birçok çalışma yapılmıştır. $\mathrm{Bu}$ çalışmalarda klorofenol kesikli veya yarı kesikli sistemlerde $\% 70$ ile $\% 100$ arasında giderim gerçekleştiği rapor edilmiştir [10-15]. Ancak son yillarda endüstriyel atık suların arıtılmasına yönelik geleneksel yöntemler arasında, aktif çamur (AS) çeşitli endüstriler tarafından yaygın bir şekilde kullanılmaktadır $[11,16,17]$. Bununla birlikte, fenolik atık suların arıtım verimliliğinin

\footnotetext{
* Sorumlu yazar / Corresponding author, e-posta / e-mail: eudeveci@ohu.edu.tr (E.Ü. Deveci)

Geliș / Recieved: 23.09.2020 Kabul / Accepted: 10.01.2021 Yayımlanma / Published: 27.07.2021

doi: $10.28948 /$ ngmuh.759297
} 
arttırılması, araştırmacılar ve endüstriler arasında büyük ilgi uyandıran önemli bir araştırma konusu haline gelmiştir [14, $15,18,19]$.

Klasik aktif çamur sisteminin inhibisyonunun önüne geçilmesi amacıyla biyofilm reaktörler oldukça dikkat çekmektedir. Biyofilm reaktörlerde kullanılan dolgu malzemesinin belirli özelliklere sahip olması gerekmektedir. $\mathrm{Bu}$ özellikler filtre malzemesi türü, parçacık çapı, şekli, özgül ağırlığı, boşluk miktarı vb. tasarım ve işletme aşamalarında önemli olmaktadır. Biyofilm reaktörlerde ister akışkan yataklı ister dolgulu kolon olsun, dolgu malzemesi olarak kum, kil, antrasit, cüruf gibi doğal özellikli maddeler kullanılabildiği gibi polipropilen, poliüretan gibi plastik özellikteki malzemeler de tercih edilebilmektedir [20]. Bu çalışmada ise uygulamaya uygun bir şekilde aktif çamur mikroorganizmalarının aklimasyonu ve dolgulu kolonda giderimi sağlanmıştır. Yukarı akışlı dolgulu kolon reaktörde dolgu malzemesi olarak mikro gözenekli poliüretan kullanılmıştır. $\mathrm{Bu}$ reaktörde askıda hücrelerin kullanılmasından ziyade immobilize hücrelerin kullanılması ilgili en önemli avantaj biyoreaktör içerisinde yüksek konsantrasyonda hücre tutulmasıdır. Ayrıca reaktör içerisinde toksik materyallere karşı hücrelerin korunmasının yanında daha yüksek arıtım verimliliği ve iyi bir işletme stabilitesi tespit edilmiştir.

\section{Materyal ve metot}

\subsection{Mikroorganizma}

Çalışmada kullanılan aktif çamur; Kayseri Büyükşehir Belediyesi Atıksu Arıtma Tesisinin geri devir ve havalandırma tankından alınmıştır. Fenolik bileşiklerin parçalanması için planlanan optimizasyon çalışması; Şekil 1'de gösterildiği gibi laboratuvarda sürekli ve havalandırmalı yukarı akışlı kolon biyoreaktörde, alıkonma

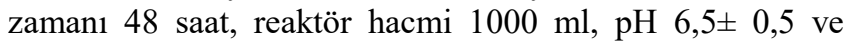
sıcaklık oda sıcaklığında çalışılmıştır. Reaktör içerisinde havalandırma, verilen hava $2 \mathrm{~L}$ /dak olacak şekilde akışı ayarlanabilir akvaryum pompalarıyla sağlanmıştır. 10 günlük çamur yaşına sahip aktif çamur ile çalışma yürütülmüştür. Sentetik klorofenol konsantrasyonu 250, 500, $750 \mathrm{ppm}$ olacak şekilde farklı 2,4-DKF konsantrasyonlarında çalışılmıştır.

Sentetik 2,4-DKF atıksuyun hazırlanış1; 0,4 g/L NaOH 1 $\mathrm{L}$ distile suda çözülerek üzerine $5 \mathrm{~g} / \mathrm{L}$ sentetik 2,4-DKF eklenerek hazırlanmıştır. Sentetik atıksu 2,4-DKF (Merck) kimyasalı ve Tablo 2'de içeriği verilen ortam içerecek şekilde hazırlanmıştır.

\subsection{Büyüme ortamı}

Kayseri Büyükşehir Belediyesi Atıksu Arıtma Tesisinin geri devir ve havalandırma tankından gelen aktif çamur laboratuvar ortamında Tablo 1'de içeriği verilen ortam ile beslenmiştir.

$\mathrm{Bu}$ büyüme ortamından alınan çamur İmhoff hunisinde çöktürüldükten sonra üst sıvı alınıp aktarıldıktan sonra fosfat tamponu eklenmiştir. Fosfat tamponu ile karıştırıldıktan sonra yeniden İmhoff hunisinde çökmesi için beklenmiştir. Yarım saat sonra çöken çamurdan üst sıvı alındıktan sonra kalan çamur eşit miktarda (MLSS 100 mg/l olacak şekilde) aklimasyon ortamına aktarılmıştır.

\subsection{Aklimasyon çalışması}

Aktif çamur mikroorganizmalarının fenol ve fenol türevi bileşikleri parçalayabilmeleri için aklime edilme süreci alıkonma zamanı öncesinde uygulanmıştır. Aklime edilme süreci için aktif çamur, Tablo 2'de verilen besiyeri içeriğinde hazırlanmış ortamlarda $250 \mathrm{~mL}$ 'lik 10 adet erlen içerisinde $100 \mathrm{~mL}$ olacak şeklide aktarılarak çalkalayıcıda inkübe edilmiştir. Bütün erlenler 25 gün boyunca sentetik 2,4-DKF çözeltisi ile belirli konsantrasyonlarda beslenmiştir [22]. Canlıların aktif olup olmadıkları nutrient broth besiyeriyle hazırlanmış tüplerle kontrol edilmiştir.

\subsection{Optimizasyon çalışması}

25 günlük inkübasyon sonunda aklime edilmiş çamurlar İmhoff hunisine aktarılmıştır. İmhoff hunisinde yarım saat çökeldikten sonra üst sıvı alınarak modifiye ortam ile yıkanmış yukarı akışlı dolgulu kolon reaktöre aktarılmıştır. Mikrobiyal çamur ilavesi yapılmamış 2,4-DKF içerikli kolon inkübasyon boyunca yukarı akışkanlı reaktörde negatif kontrol örnek olarak işletilmiştir. Akışkan kolonların hava çıkışları seçici geçirgen filtre ile kapatılarak havalandırma sağlıklı bir şekilde sağlanırken fenolün kaçışı da engellenmiştir. Böylece 2,4-DKF'nin \%95 oranında uzaklaşmadığı belirlenmiştir. Bu çalışma kapsamında, farklı konsantrasyonlarda 2,4-DKF akış hızına bağlı olarak fenol giderimi incelenmiş ve optimum akış hızı ve fenol konsantrasyonu belirlenmiştir.

\subsection{Analitik metotlar}

Deneysel çalışmalarda pH ölçümü, sıcaklık, iletkenlik ve çözünmüş oksijen WTW inolab_IDS multi 9430 cihazı ile yapılmıştır. MLSS tayini standart metodlara uygun olarak yapılmıştır (Standard Methods, 1998). ORP (OksidasyonRedüksiyon potansiyeli) ölçümleri SANXIN SX712 Marka cihazla standart metodlara uygun şekilde ölçümleri yapılmıştır. KOİ (Kimyasal Oksijen İhtiyacı) analizleri, açık refluk standart metodlara uygun olarak yapılmıştır. Toplam Fenol analizi; standart metodlara uygun olarak yapılmıştır.

\section{Bulgular ve tartışma}

Farklı fenol konsantrasyonlarında giriş konsantrasyonlarına sahip sentetik atıksular, $750 \mathrm{~mL}$ çalışma hacmine sahip $0,5 \times 0,5 \times 0,5 \mathrm{~mm}$ ölçülere sahip poliüretan malzemelerle 2/3'ü doldurulmuş yukarı akışlı dolgulu kolonda $2 \mathrm{~mL} /$ dak akış hızında 25 gün boyunca sürekli sistemde işletilmiştir. Sistem içerisinde kullanılan aklime edilmiş mikroorganizmalar günlük çamur yaşına sahiptir. Günlük alınan örneklerde KOİ, toplam fenol, ORP, pH ve elektriksel iletkenlik analizleri yapılmıştır. Fenol konsantrasyonunun etkisinin belirlenmesi için yapilan deneylerde başlangıç fenol konsantrasyonunun ayarlanması için ilk girişte fenol ve fenol parçalanma ürünleri tampon çözelti ile yıkanarak alınmıştır. Giriş fenol konsantrasyonları 250, 500 ve $750 \mathrm{mg} / \mathrm{L}$ olarak kullanılmıştır. Bulunan optimum giriş fenol konsantrasyonuna bağlı olarak 1, 2, 3 $\mathrm{mL} / \mathrm{dk}$ akış hızında fenol ve organik yük giderim verimi incelenmiştir. 


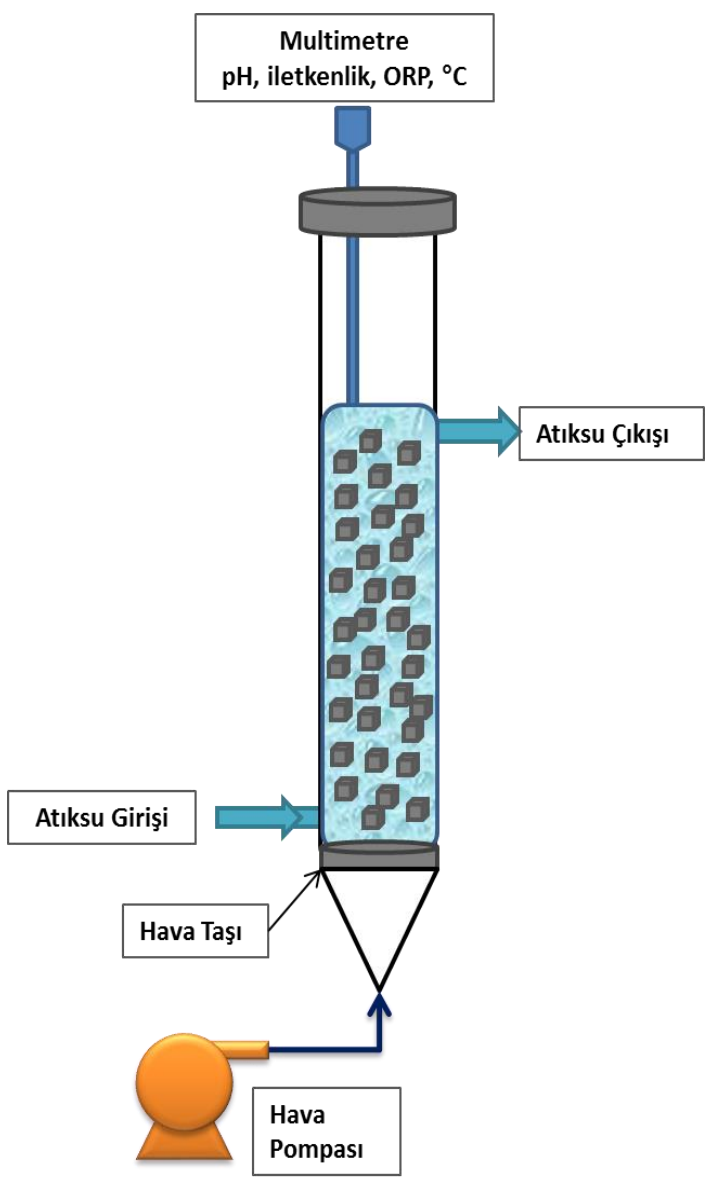

Şekil 1. Sürekli sistem yukarı akışlı kolon reaktör

Tablo 1. Aktif çamurun besiyeri içeriği [21]

\begin{tabular}{|c|c|}
\hline Kimyasalın adı & Konsantrasyonu $(\mathrm{g} / \mathrm{L})$ \\
\hline $\begin{array}{c}\mathrm{K}_{2} \mathrm{HPO}_{4} \\
\left(\mathrm{NH}_{4}\right)_{2} \mathrm{SO}_{4} \\
\mathrm{KH}_{2} \mathrm{PO}_{4} \\
\text { Peynir alt1 suyu tozu }\end{array}$ & $\begin{array}{c}0.5 \\
0.94 \\
0.25 \\
1.0\end{array}$ \\
\hline \multicolumn{2}{|c|}{ Tablo 2. Modifiye optimizasyon ortam } \\
\hline Ortam içeriği & Konsantrasyon $(\mathrm{g} / \mathrm{L})$ \\
\hline $\begin{array}{l}\text { Glikoz } \\
\text { Pepton } \\
\text { Üre } \\
\left(\mathrm{NH}_{4}\right)_{2} \mathrm{SO}_{4} \\
\mathrm{KH}_{2} \mathrm{PO}_{4} \\
\mathrm{~K}_{2} \mathrm{HPO}_{4} \\
\mathrm{M}_{1}(1 \mathrm{~mL} / \mathrm{L}) \\
\mathrm{FeSO}_{4} .7 \mathrm{H}_{2} \mathrm{O} \\
\mathrm{ZnSO}_{4} \cdot 7 \mathrm{H}_{2} \mathrm{O} \\
\mathrm{MnSO}_{4} \cdot \mathrm{H}_{2} \mathrm{O} \\
\mathrm{CuSO}_{4} \cdot 5 \mathrm{H}_{2} \mathrm{O} \\
\mathrm{CaCl}_{2} \cdot 6 \mathrm{H}_{2} \mathrm{O}\end{array}$ & $\begin{array}{c}1 \\
0,1 \\
0,2 \\
0,1 \\
0,1 \\
0,1 \\
\\
1,5 \\
0,5 \\
0,3 \\
0,075 \\
0,015\end{array}$ \\
\hline Sitrik Asit & 0,6 \\
\hline $\begin{array}{l}\mathrm{M}_{2}(1 \mathrm{~mL} / \mathrm{L}) \\
\left(\mathrm{NH}_{4}\right)_{6} \mathrm{Mo}_{7} \mathrm{O}_{24} \cdot 4 \mathrm{H}_{2} \mathrm{O} \\
\mathrm{H}_{3} \mathrm{Bo}_{3}\end{array}$ & $\begin{array}{l}0,05 \\
0,01\end{array}$ \\
\hline KI & 0,01 \\
\hline 2,4 Diklorofenol & 5 \\
\hline
\end{tabular}




\subsection{Başlangıç fenol konsantrasyonunun fenol ve KOI giderimine etkisi}

Başlangıç fenol konsantrasyonunun KOİ giderimi üzerine etkisi belirlenmiștir. Elde edilen verilere göre fenol konsantrasyonunun artışı fenol giderimini azaltmış̧ır. KOİ giderimi sırasında dalgalanmalar fenolik yapıların parçalanması sırasında oluşan yan ürünlerden kaynaklanmaktadır. Moussavia ve ark (2014) tarafindan yapılan çalışmada KOİ değerinin biyodegradasyon sırasında zamana bağlı olarak azalışında değişkenlik gösterdiği ve aklimasyon süresinin 5 ile 30 gün arasında değişiklik göstereceği belirlenmiştir [22]. Yapılan bu çalıșmada aklimasyon süresi 25 gün olarak belirlenmiştir. Aklime edilmiş mikroorganizmalar 21 günlük işletim süresi boyunca giderim veriminde önemli bir değişim gözlenmediği ve poliüretan malzemenin biyofilm kalınlığının sabit olduğu Şekil 2'de verilen SEM (Taramalı Elektron Mikroskobu) analizleri ile belirlenmiştir.

Mikro gözenekli poliüretan (sünger) immobilizasyon malzemesi olarak kolay temin edilmesi ve ucuz olması açısından tercih edilmiştir. Elde edilen SEM görüntülerine göre biyofilm kalınlığının belli bir seviyeye kadar oluştuğu ve deneysel çalışmada immobilizasyonun sağlandığı belirlenmiștir.

Akış hızı $2 \mathrm{~mL} / \mathrm{dk}$ olarak ayarlanan kolonda giderim 250 $\mathrm{mg} / \mathrm{L}$ ve $500 \mathrm{mg} / \mathrm{L}$ fenol konsantrasyonlarında gideriminin \% 85-90 aralığında değiștiği bu durumun reaktörün ișletimi sırasında herhangi bir değișiklik göstermediği belirlenmiștir. Şekil 3a'da görüldüğü üzere ortamda bulunan 2,4-DKF içeriğinin her giris konsantrasyonunda verimli bir sekilde arıtıldığı ancak $750 \mathrm{mg} / \mathrm{L}$ 'lik koşulda $250 \mathrm{mg} / \mathrm{L}$ ve $500 \mathrm{mg} / \mathrm{L}$ konsantrasyonlarındaki giderime göre düşük olduğu belirlenmiştir. Barlak ve ark. tarafindan yapılan çalışmada elde edilen sonuçlar bu çalışmada elde edilen sonuçlara uygun bir șekilde; jet döngülü reaktörde ve kabarcık kolonunda ozonlama ile fenol giderimi karşılaştırmasında; jet döngülü reaktör de $\mathrm{pH} 11$ 'de $\% 96$ fenol giderimi ve $\% 55$ 65 arası KOİ giderimi gerçekleşirken kabarcık kolonda ozonlama ile $\mathrm{pH} 7.5$ ve 2.2 'de $\% 84$ fenol giderimi ve $\% 56$
KOİ giderimi gözlendiği bildirilmiștir. Düşük $\mathrm{pH}$ ve yüksek ozonlanma maliyeti ile kabarcık kolonda ozonlama tekniği yerine jet döngülü reaktör fenol gideriminde tercih edileceği rapor edilmiştir [23].

Şekil 3b'den anlaşılacağ dikolorofenol içeriği aklime olmuş aktif çamur mikroorganizmaları açısından oldukça toksik seviyedir. $\mathrm{Bu}$ toksik seviyenin belirlenmesi için reaktör 90 gün boyunca işletilerek 30 gün aralıklarla sürekli sistemde verilen 2,4DKF içeriği artırılmıștır. Elde edilen sonuçlara göre akıștaki 2,4-DKF $750 \mathrm{mg} / \mathrm{L}$ 'ye çıkarılması ortamdaki mikrobiyolojik aktiviteyi sınırlamakta ve toksik seviyeye ulaştığını göstermektedir. P. putida ve P. Alcaligenes için 2,4-DCP'den $125 \mathrm{mg}$ / L'ye kadar minimal inhibitör konsantrasyon $220 \mathrm{mg}$ / L bulunurken [24]; Şahinkaya ve Dilek [25] tarafindan yapılan çalışmada aklime edilmiş aktif çamur mikroorganizmaları aerobik kesikli reaktörler kullanarak 4CP (4-klorofenol) parçalama yetenekleri açısından incelendiğinde $300 \mathrm{mg} / \mathrm{L}$ 'ye kadar karışık kültürde bir inhibisyon gözlenmediği belirlenmiş̧ir.

Sekil 4'de gösterildiği gibi 90 günlük sürekli sistem çalışmasında giriş suyundaki 2,4-DKF değeri 30 gün aralıklarla değiştirilmiş ve elde edilen deneysel verilere göre; $250 \mathrm{mg} / \mathrm{L}$ ve $500 \mathrm{mg} / \mathrm{L}$ aralığında atıksu da arıtım verimliliği oldukça yüksek iken $750 \mathrm{mg} / \mathrm{L}$ 2,4-DKF konsantrasyonun de giderim verimi oldukça düșmüştür. KOİ giderimi sırasında zamana bağlı olarak görülen giderimdeki dalgalanmanın nedenlerinden biri; dolgulu kule içerisindeki fenolik birleşiklerin parçalanmasından sonra yan ürünlerin KOİ değerlerini yükseltmesi olabilir. Diğer bir nedeni ise 2,4DKF'nin biyolojik olarak parçalanması sonrası oluşan ara ürünler mikrobiyolojik olarak toksik etkiye sahip olması olabilir. Düşük konsantrasyonlarda oluşan ara ürünler düşük iken yüksek konsantrasyonda artmıştır. Bu nedenle Şekil 3 'de görüldüğü üzere fenol değeri arttıkça dalgalanmalar daha fazla olur.

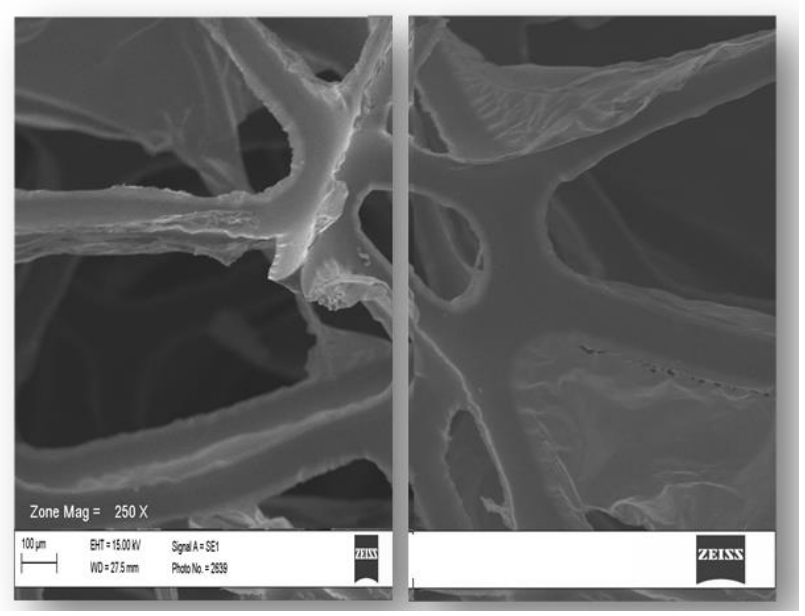


Şekil 2. Çalışmada kullanılan immobilize malzeme poliüretanın SEM görüntüsü (a. immobilizasyon öncesi b. alıkonma zamanı sonras1)

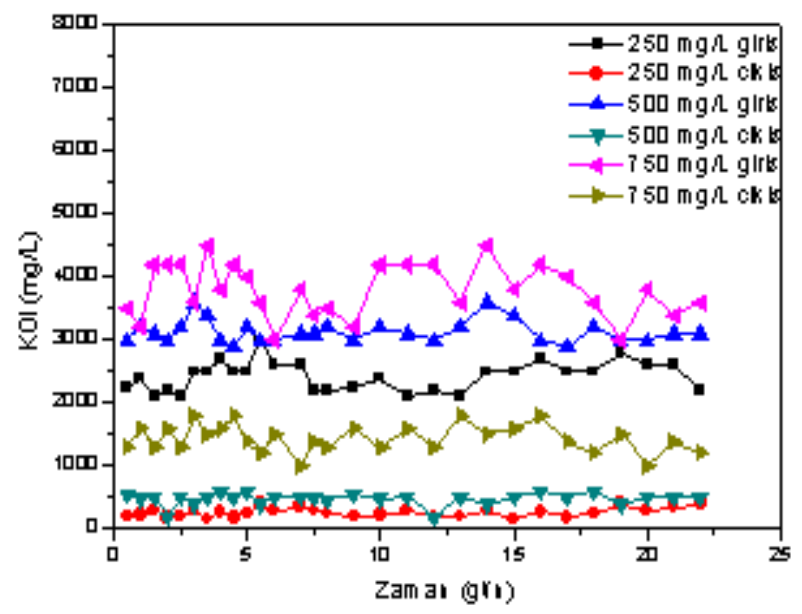

(a)

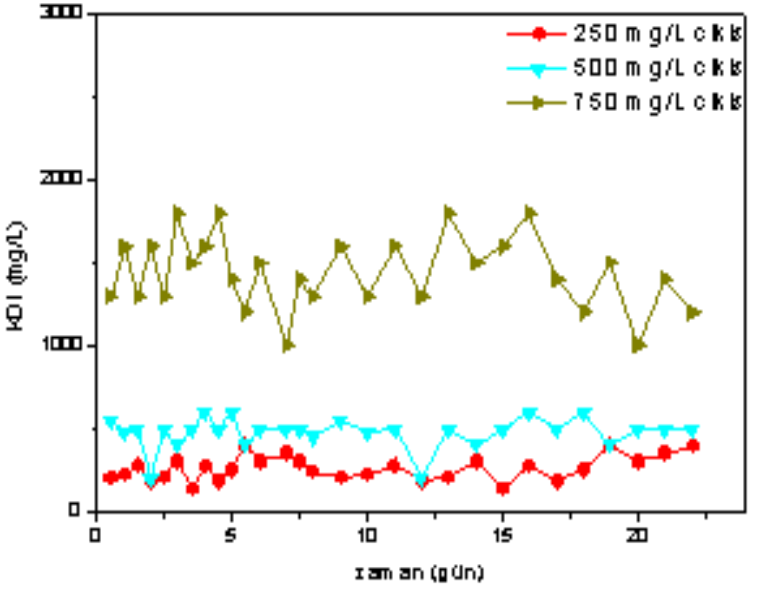

(b)

Şekil 3. Başlangıç fenol konsantrasyonun KOİ giderimi üzerine etkisi (a. giriş ve çıkış değerleriyle b. çıkış değerleri)

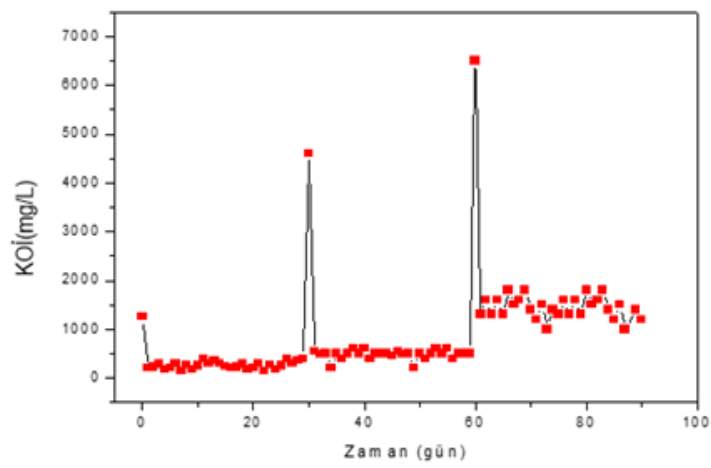

Şekil 4. Sürekli sistemde 90 gün boyunca KOİ üzerine farklı fenol yüklemelerinin etkisi

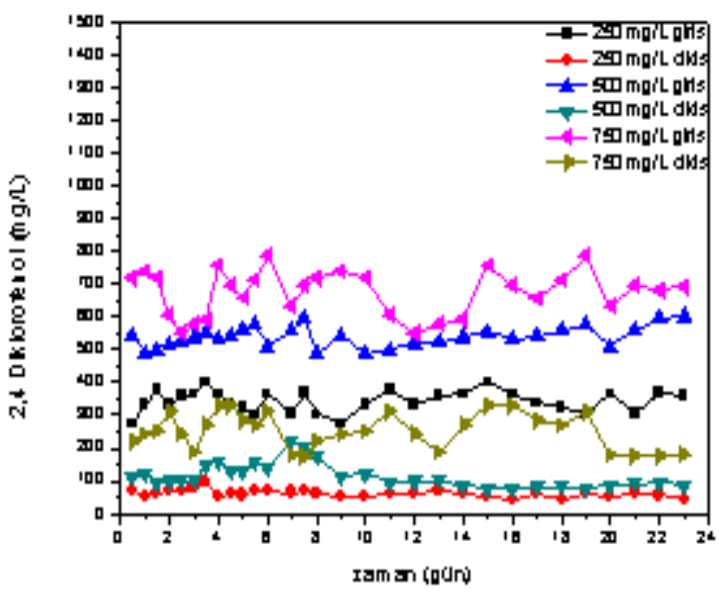

(a)

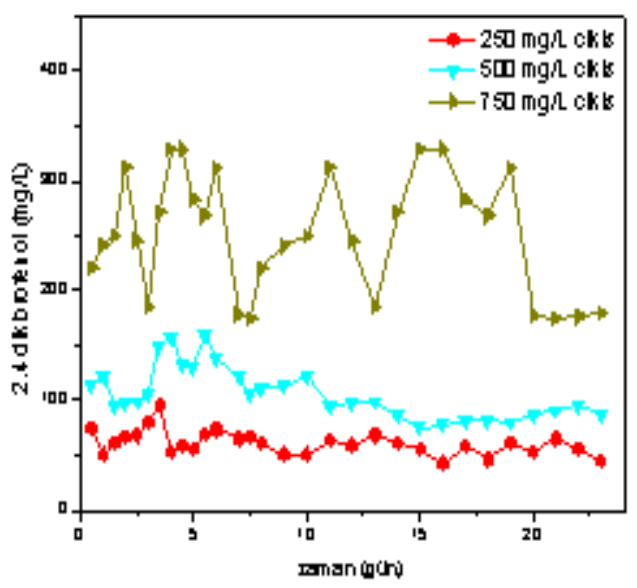

(b) 
Şekil 5. Başlangıç fenol konsantrasyonunun fenol giderimi üzerine etkisi (a. giriş ve çıkış, b. çıkış değerleri)

Moussavia ve ark (2014) tarafindan yapılan çalışmada KOİ değerinde zamana bağlı olarak oldukça değişken salınımlar gözlenmiştir. $200 \mathrm{mg} / \mathrm{L}$ Fenol içeriğine sahip atıksuda \% 99 KOİ ve fenol giderimi olduğu belirlenmiştir [22]. Gupta ve ark. nın fenol giderime üzerine yaptığ çalışma ise yaptığımız çalışma ile benzerlik göstermektedir. Gupta ve ark. çay atıkları üzerinde Bacillus. immobilize edilerek fenol giderimi gerçekleştirilmiş ve elde dilen verilere göre \% 70-80 arası fenol giderimi gerçekleştiği rapor edilmiştir [26]. Yapılan bu çalışmada ise $250 \mathrm{mg} / \mathrm{L}$ fenol içeren atıksuda $\% 84,500 \mathrm{mg} / \mathrm{L}$ fenol içeren atıksuda $\% 86$ giderim olduğu bulunmuştur. Bu durum Moussavia ve ark. tarafından yapılan çalışma ile paralellik göstermektedir.

Başlangıç fenol konsantrasyonunun fenol giderimi üzerine etkisi Şekil 5'de incelenmiştir. Elde edilen verilere göre fenol konsantrasyonunun artışı fenol giderim verimini düşürmüştür. Bunun nedeni fenol konsantrasyonun artışı ve 2.4-DKF'nin toksik etkisinin konsantrasyon artışına bağlı olarak artmasından kaynaklıdır. Şekil 6'de sürekli sistemde 90 gün boyunca reaktörde zamana bağlı olarak artan fenol yüklemesine karşı giderim grafiği verilmiştir. Şekil 6'dan da anlaşıldığı üzere fenol konsantrasyonundaki ani değişimler parçalama üzerinde ciddi etkiler yaratmamış ancak fenol konsantrasyonu $750 \mathrm{mg} / \mathrm{L}$ 'e ulaştığında giderimde salınımlar gözlenmiştir. $\mathrm{Bu}$ durum fenolün toksisitesi ile direk ilgili olduğu düşünülmektedir. Ayrıca Şekil 6'da yer alan fenol yüklemelerinin etkisi Şekil 5b'de fenol giderimi grafiğinde $750 \mathrm{mg} / \mathrm{L}$ 2,4-DFK içerikli atıksuyun aklime olmuş mikroorganizmalarla gideriminde ortam organik içeriğinin dalgalanarak sürekli başlangıç seviyesine hatta ara ürünler yüzünden başlangıçtan yüksek organik yük varmış gibi davranmaktadır. Bu durum 2,4-DFK'ün biyolojik olarak parçalanmasından kaynaklanabilir. $250 \mathrm{mg} / \mathrm{L}$ fenol içeriğine sahip atıksuda fenol giderimi gerçekleştiği Şekil 5b'de görülmektedir. $500 \mathrm{mg} / \mathrm{L}$ fenol konsantrasyonuna sahip atıksuda başlangıçta fenol konsantrasyonu artsa da zamana bağlı olarak azalmaya geçmiștir. $\mathrm{Bu}$ durum belli bir konsantrasyona kadar mikroorganizmaların aktivitesinin devam ettiğini ve fenolün düşük konsantrasyonlarında da olsa giderildiği gözlenmektedir. Başak ve ark. yaptığ çalışmada şeker kamışı küspesi üzerine C. Tropicalis mikroorganizması immobilizasyonu ile oluşturulan paket yataklı reaktörde fenol giderimi çalışması gerçekleştirilmiştir. Bu çalışmada reaktör içerisinde 64 mg/g.sa maksimum biyolojik bozunma hızında \%94 fenol giderimi tespit edilmiştir [27].

2,4-DKF doğa için karsinolojik özelliğe sahip bir kimyasal olup genel olarak pestisit üretiminde yoğun olarak kullanılmaktadır. Bu nedenle evsel atıksularda bulunma olasılığı yüksektir. $\mathrm{Su}$ içerisinde mikro seviyelerde bulunması arıtma sistemleri için problem yaratmamakta ancak $500 \mathrm{mg} / \mathrm{L}$ 'nin üzerindeki 2,4-DKF konsantrasyonu arıtma verimliliğini etkileyebilmektedir. Şekil 7'de da görüldüğü üzere fenol konsantrasyonunun artışı fenol giderimini düşürmüştür. Aklime edilmiş aktif çamur isteminde optimal giderim veriminin $500 \mathrm{mg} / \mathrm{L} \mathrm{2,4-DFK}$ değerinde elde edildiği belirlenmiştir. $750 \mathrm{mg} / \mathrm{L}$ 'lik fenol konsantrasyonunda giderim oranını 500 mg/L'ye göre düşük olup $500 \mathrm{mg} / \mathrm{L}$ 'den sonra ortamdaki 2,4-Dikolorofenol içeriği toksik etki yaratmaya başladığı görülmektedir. Bu durum $750 \mathrm{mg} / \mathrm{L}$ 2,4-DFK değerinin toksik seviye olduğu tespit edilmiştir.

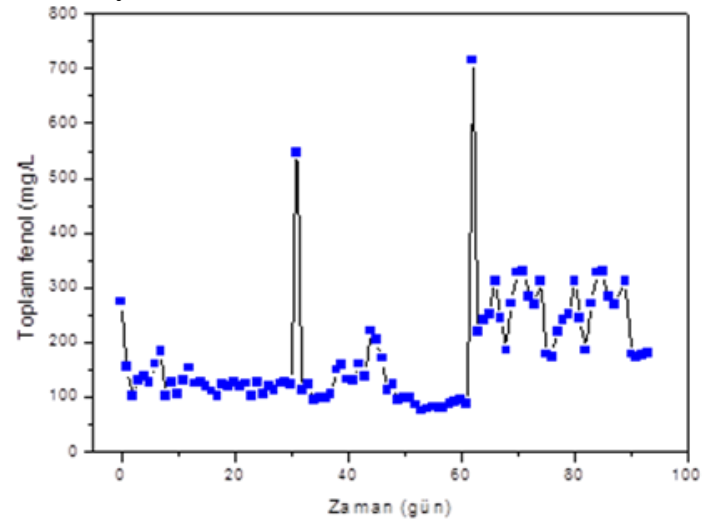

Şekil 6. Sürekli sistemde 90 gün boyunca fenol üzerine farklı fenol yüklemelerinin etkisi

Fenol konsantrasyonu arttıkça KOİ'deki dalgalanmalar da artar. Buna bağlı olarak fenolik bileşiklerdeki parçalamaların olduğu da Şekil 8'de verilen ORP sonuçlarından anlaşılmaktadır. Sürekli sistemde sürekli olarak izlenen belli aralıklarda verilerin ișlendiği Şekil 8'e göre, ORP verilerinde belirgin dalgalanmalar gözlenmiştir. $\mathrm{Bu}$ durum 2,4-DKF'nin parçalanması sorucu oluşan yükseltgenme potansiyellerinde değişikliğine ayrıca dalgalanmanın sürekli olarak devam etmesi parçalanmanın sürekli olduğunu göstermektedir. Ortamdaki 2,4-DFK değişimine bağlı olarak Şekil 8 incelendiğinde 2,4-DFK derişminin ortamda artması ile ORP değeri daha yüksek olmasının yanında diğer düşük konsantrasyonlardaki dalgalanmalara benzerlik göstermiştir. Bu durum ise 2.4DFK'ün yüksek konsantrasyonlarda düşük verimde olsa dahi parçalanmaya devam ettiğini gösterebilmektedir.

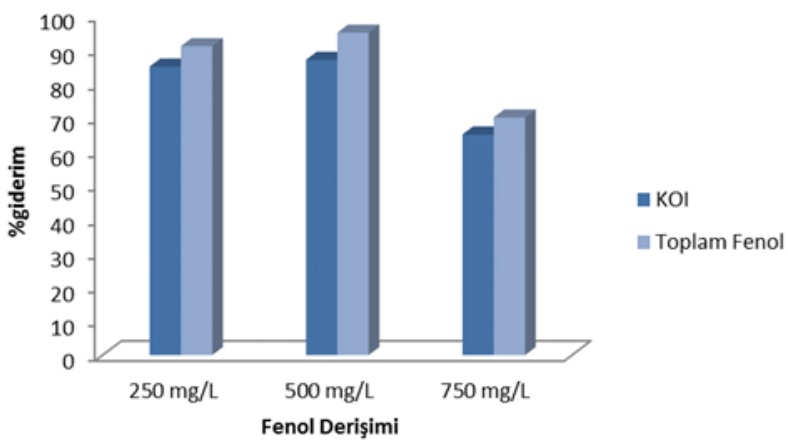

Şekil 7. Fenol Konsantrasyonunun KOİ ve fenol giderimine etkisi 
Sürekli sistem içerisine yerleştirilmiş problar yardımıyla sürekli olarak iletkenlik değeri izlenmiş elde edilen veriler belli zaman aralıklarında alınarak Şekil 9'daki gibi

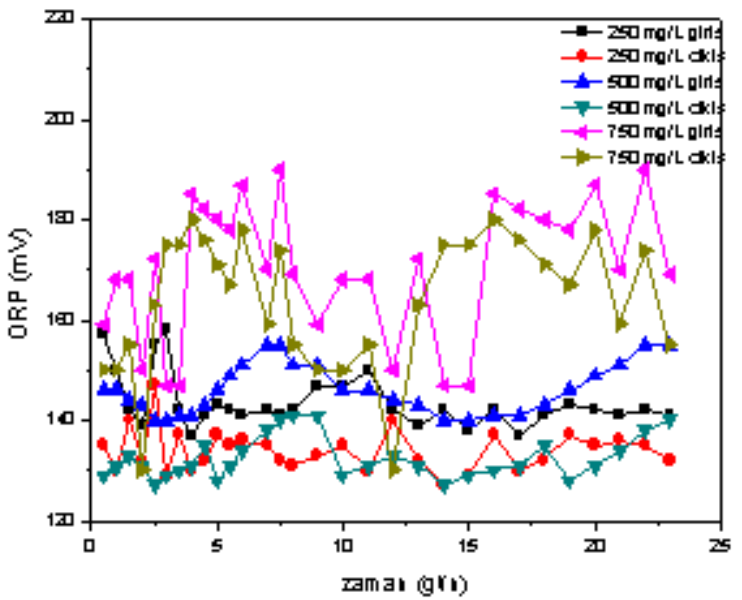

(a) grafiklendirilmiştir. Elde edilen Şekil 9a' ya göre elektriksel iletkenlik ortam içeriğindeki çözünmüş madde içeriğine göre farklılık göstermektedir.

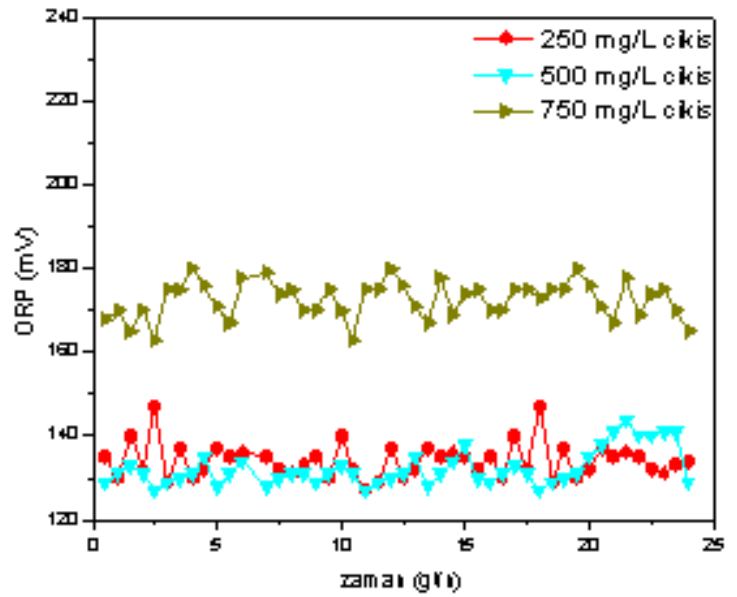

(b)

Şekil 8. Farklı fenol konsantrasyonunun ORP değerindeki değişimlere etkisi (a. giriş ve çıkış değerleriyle b. çıkış değerleri)

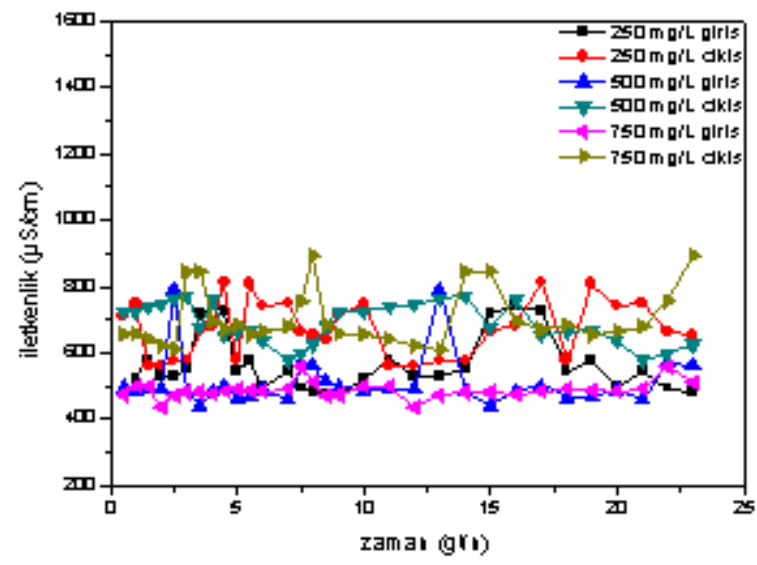

(a)

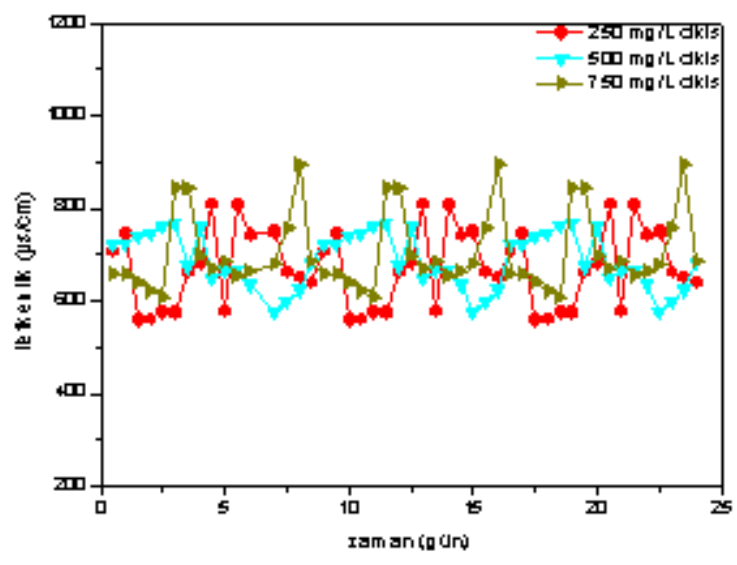

(b)

Şekil 9. Farklı fenol konsantrasyonunun elektriksel iletkenlik değerindeki değişimlere etkisi (a. giriş ve çıkış değerleriyle b. çı1kş değerleri)

Şekil 9a’dan görüldüğü üzere çıkıș suyundaki elektriksel iletkenlik değeri fermentasyon ortamına göre daha düşük seviyenin yanında dalgalanma girişe göre daha azdır. $\mathrm{Bu}$ duruma 2.4-DKF’ün parçalanmasının izlenmesinde elektriksel iletkenlik ve ORP değişiminin izlenmesi mikrobiyal aktivite ve giderim hakkında önemli bir bilgi verdiğini göstermektedir. Deveci (2018) tarafindan yapılan kesikli istem çalışmasında da ORP ve elektriksel iletkenlik değerleri parçalanmanın hızına ve süresine bağlı olarak değiştiği belirlenmiştir. Elde edilen verilere göre; analizi kolay ve maliyeti düşük ORP ve elektriksel iletkenlik analizleri, COD ve Fenol analizlerini destekleyecek niteliktedir [21]. Jiang ve ark. tarafindan Alcalıgenes faecalis ile bir fenol giderimi üzerine yapılan çalışmada 76 saatlik bir inkübasyon süresi sonunda aklime olmuş türlerin 1.600
mg/L'nin maksimum seviyede giderildiği tespit edilirken inkübasyon sırasında takip edilen fiziksel parametreler de incelenmiştir. Fiziksel parametrelerde önemli değişikliğin sebebi biyolojik bozunma ve yan ürünlerden kaynaklanabileceği çalışmada da rapor edilmiştir [28]. Aynı durum $\mathrm{pH}$ değerinin izlenmesinde gözlenmemiştir. İndirgenme yükseltgenmede gerçekleşen değişim ortam $\mathrm{pH}$ değerini belirgin şekilde değiştirmemektedir. Farklı fenol giriș konsantrasyonlarında stok pH değeri 6,0-6,5 arasında tutulmuştur. Çıkış pH değerleri ise $6,6-7,7$ arasında kalmıştır.

\subsection{Akış hızının fenol giderimine etkisi}

Yukarı akışlı reaktörlerin bir avantajı yüksek organik yüklerin verimli bir şekilde kullanılabilmesidir. Bu durumu 
sürekli sistemde hidrolik akış hızı ile incelendiğinde akış hızının artışı fenol ve KOİ giderimini önemli seviyede etkilediği belirlenmiştir. Şekil 11 'de görüldüğü gibi akış hızı $2 \mathrm{~mL} / \mathrm{dk}$ olarak ayarlanan kolonda giderimin \%85-90 aralığında değiştiği görülmüştür. Elde edilen sonuçlara göre akış hızındaki artış giderim verimini düşürmektedir. Optimum akış hızı yapılan çalışmada $2 \mathrm{~mL} / \mathrm{dk}$ olarak belirlenmiştir. Aksu ve Gönen tarafindan yapılan sürekli dolgulu reaktörde aktif çamur mikroorganizmaları ile fenol giderimi çalışmasında $0.8 \mathrm{~mL} / \mathrm{dk}$ akış hızında maksimum fenol giderimi gerçekleştiği ve akış hızı yükseldikçe fenol gideriminin düştüğü bildirilmiştir. Ayrıca kesme noktası süresi ve toplam adsorbe edilen fenol miktarı da artan akış hızı ile azaldığı ve bu durumun aktif çamur biyokütlesinin fenol biyosorpsiyonunda çözünen maddenin kolondaki yetersiz kalış süresinden etkilendiği rapor edilmiştir [29].

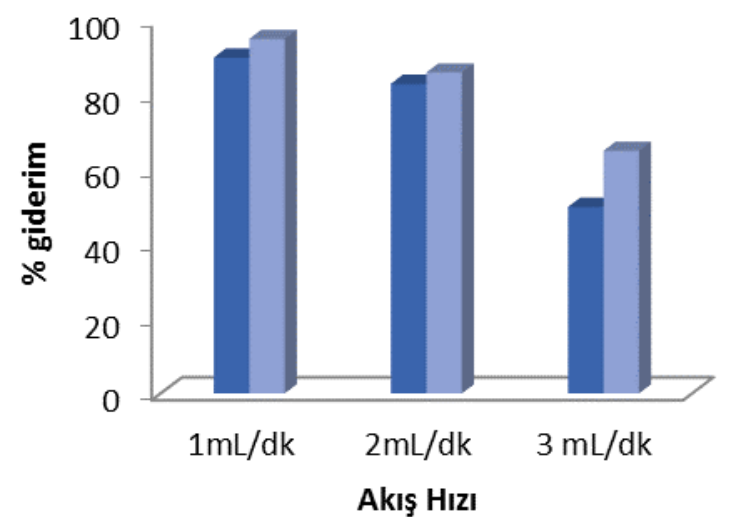

Şekil 11. Akış hızının fenol ve KOİ giderimi üzerine etkisi

\section{Sonuçlar}

Çalışmada 2,4-DKF'ün aklime olmuş aktif çamur mikroorganizmalarıyla biyodegradasyonu ve uzaklaştırılması çalışması yürütülmüştür. Çalışmada biyolojik bozunma ORP, elektriksel iletkenlik, KOİ ve fenol değişimi ile belirlenmiştir. 2.4-DKF'nin parçalanması sırasında oluşan ara ürünlerin zamana bağlı olarak değişimleri incelendiğinde ORP değerinde ve elektriksel iletkenlikte belirgin dalgalanmanın olduğu belirlenmiştir. Aynı dalgalanma benzer şekilde zamana bağlı azalan eğilimde KOİ değerinde belirgin olarak gözlenmiştir. Bu çalışma ile $500 \mathrm{mg} / \mathrm{L}$ 'de $\% 83 \mathrm{KOİ} \mathrm{ve} \mathrm{\% 86} \mathrm{fenol} \mathrm{giderimi}$ sağlanmıştır. $750 \mathrm{mg} / \mathrm{L} \mathrm{2,4-DKF} \mathrm{konsantrasyonunun} \mathrm{aklime}$ olmuş aktif çamur mikroorganizmaları için toksik seviyede olduğu KOİ ve Fenolün zamana bağlı değişimlerinin incelenmesi sırasında açıkça görülmüştür. Çalışmada her bir 2,4-DKF konsantrasyonu ayrı ayrı 21 gün işletilmiş, sürekli sistem içerisindeki değişimin izlenmesi için ise 90 gün boyunca 2,4-DKF değeri arttırılarak işletilmiştir.

Son derece tehlikeli ve kanserojen özelliğe sahip bu tip atıksuların özel olarak değerlendirilmesi gerekmektedir. Bu çalışma ile özellikle endüstriyel tesislerin olduğu organize sanayi bölgelerinin arıtma sistemlerine modifiye edilerek yüksek arıtım verimliliği sağlanabilir. Ayrıca çalışmanın geliştirilmesi için aktif çamur içerisinden izole edilecek özel bakteri türleri ile çalışmalar yapılabilir.

\section{Çıkar çatışması}

Yazarlar çıkar çatışması olmadığını beyan etmektedir.

\section{Benzerlik oranı (iThenticate): $\% 8$}

\section{Kaynaklar}

[1] R. Mtibaà et al., Biodegradation and toxicity reduction of nonylphenol, 4-tert-octylphenol and 2,4dichlorophenol by the ascomycetous fungus Thielavia sp HJ22: Identification of fungal metabolites and proposal of a putative pathway. Sci. Total Environ., 708, 2020.doi: 10.1016/j.scitotenv.2019.135129.

[2] T. Rasheed, M. Bilal, C. Li, F. Nabeel, M. Khalid, and H. M. N. Iqbal, Catalytic potential of bio-synthesized silver nanoparticles using Convolvulus arvensis extract for the degradation of environmental pollutants. J. Photochem. Photobiol. B Biol., 181, 44-52, 2018.doi: 10.1016/j.jphotobiol.2018.02.024.

[3] I. B. Gomes, L. C. Simões, and M. Simões, The effects of emerging environmental contaminants on Stenotrophomonas maltophilia isolated from drinking water in planktonic and sessile states. Sci. Total Environ., 643, 1348-1356, 2018.doi: 10.1016/ j.scitotenv.2018.06.263.

[4] Y. Luo et al., A review on the occurrence of micropollutants in the aquatic environment and their fate and removal during wastewater treatment. Sci. Total Environ., 473-474, 619-641, 2014.doi: 10.1016/ j.scitotenv.2013.12.065.

[5] A. A. Oluwasanu, Fate and toxicity of chlorinated phenols of environmental 1mplications: A Review. Med. Anal. Chem. Int. J., 2(4), 2018.doi: 10.23880/ macij-16000126.

[6] S. M. Blunt et al., Association between degradation of pharmaceuticals and endocrine-disrupting compounds and microbial communities along a treated wastewater effluent gradient in Lake Mead. Sci. Total Environ., 622(623), 1640-1648, 2018. doi: 10.1016/ j.scitotenv.2017.10.052.T .

[7] P. Van Aken, R. Van den Broeck, J. Degrève, and R. Dewil, The effect of ozonation on the toxicity and biodegradability of 2,4-dichlorophenol-containing wastewater. Chemical Engineering Journal, 280. 728 736, 2015.doi: 10.1016/j.cej.2015.06.019.

[8] N. C. Saha, F. Bhunia, and A. Kaviraj, Toxicity of phenol to fish and aquatic ecosystems. Bull. Environ. Contam. Toxicol., 63(2), 195-202, 1999.doi: 10.1007/ s001289900966.

[9] WHO, Pharmaceuticals in Drinking Water: Public Health and Environment Water, Sanitation, Hygiene and Health, 2011.

[10] H. Cabana, J. P. Jones, and S. N. Agathos, Elimination of endocrine disrupting chemicals using white rot fungi and their lignin modifying enzymes: A review, Eng. Life Sci., 7(5), 429-456, 2007.doi: 10.1002/ elsc. 200700017. 
[11] Z. Huang et al., Toxicity mechanisms and synergies of silver nanoparticles in 2,4-dichlorophenol degradation by Phanerochaete chrysosporium. Journal of Hazardous Materials, 321. 37-46, 2017.doi: 10.1016/ j.jhazmat.2016.08.075.

[12] T. Janicki, M. Krupiński, and J. Długoński, Degradation and toxicity reduction of the endocrine disruptors nonylphenol, 4-tert-octylphenol and 4cumylphenol by the non-ligninolytic fungus Umbelopsis isabellina. Bioresour. Technol., 200, 223 229, 2016.doi: 10.1016/j.biortech.2015.10.034

[13] R. K. Rajendran, S.-L. Huang, C.-C. Lin, and R. Kirschner, Biodegradation of the endocrine disrupter 4tert-octylphenol by the yeast strain Candida rugopelliculosa RRKY5 via phenolic ring hydroxylation and alkyl chain oxidation pathways, Bioresour. Technol., 226, 55-64, 2017.doi: 10.1016/ j.biortech.2016.11.129.

[14] M. Bajaj, C. Gallert, and J. Winter, Biodegradation of high phenol containing synthetic wastewater by an aerobic fixed bed reactor. Bioresour. Technol., 99(17), 8376-8381, 2008.doi: 10.1016/j.biortech.2008.02.057.

[15] G. Mujtaba, M. Rizwan, G. Kim, and K. Lee, Removal of nutrients and COD through co-culturing activated sludge and immobilized Chlorella vulgaris. Chemical Engineering Journal, 343. 155-162, 2018.doi: 10.1016/ j.cej.2018.03.007.

[16] H. Li et al., Production of polyhydroxyalkanoates by activated sludge: Correlation with extracellular polymeric substances and characteristics of activated sludge. Chem. Eng. J., 361, 219-226, 2019.doi: 10.1016/j.cej.2018.12.066.

[17] Q. Yu et al., Bioaugmentated activated sludge degradation of progesterone: Kinetics and mechanism. Chemical Engineering Journal, 352.214-224, 2018.doi: 10.1016/j.cej.2018.06.159.

[18] X. Liu, W. Yuan, M. Di, Z. Li, and J. Wang, Transfer and fate of microplastics during the conventional activated sludge process in one wastewater treatment plant of China. Chem. Eng. J., 362, 176-182, 2019.doi: 10.1016/j.cej.2019.01.033.

[19] M. Cai et al., Improving dewaterability and filterability of waste activated sludge by electrochemical Fenton pretreatment. Chem. Eng. J. 362, 525-536, 2019.doi: 10.1016/j.cej.2019.01.047.
[20] D. Dölgen and M. N. Alparslan, Biyolojik filtre reaktörler (BFR) için dolgu malzemesi alternatifleri. DEÜ Mühendislik Fakültesi Fen Ve Mühendislik Derg., 4(3), 13-26, 2002.

[21] E. Ü. Deveci, Treatibility of wastewater containing 2,4 dichlorophenol using aclimated activated sludge microorganisms in packed upflow column bioreactor. Polish J. Environ. Stud., 27(5), 1997-2005, 2018.doi: 10.15244/pjoes/78045.

[22] A. Nuhoglu and B. Yalcin, Modelling of phenol removal in a batch reactor. Process Biochem., 40(3-4), 1233-1239, 2005.doi: 10.1016/j.procbio.2004.04.003.

[23] M. S. Barlak, N. Değermenci, İ. Cengiz, H. Ucun Özel, and E. Yildiz, Comparison of phenol removal with ozonation in jet loop reactor and bubble column. J. Environ. Chem. Eng., 8(5), no. 104402, 2020. doi.org/10.1016/j.jece.2020.104402.

[24] I. Gallizia, S. McClean, and I. M. Banat, Bacterial biodegradation of phenol and 2,4-dichlorophenol. J. Chem. Technol. Biotechnol., 78(9), 959-963, 2003.doi: 10.1002/jctb.890.

[25] E. Sahinkaya and F. B. Dilek, Biodegradation of 4chlorophenol by acclimated and unacclimated activated sludge - Evaluation of biokinetic coefficients. Environ. Res., 99(2), 2, 243-252, 2005. https://doi.org/10.1016/j.envres.2004.11.005.

[26] K. Kumar Gupta and D. Devi, Biodegradation of low density polyethylene by selected bacillus sp. Gazi Univ. J. Sci., 32(3), 802-813, 2019.doi: 10.35378/gujs.496392.

[27] B. Basak et al., Biodegradation of high concentration phenol using sugarcane bagasse immobilized Candida tropicalis PHB5 in a packed-bed column reactor. Ecotoxicol. Environ. Saf., 180, 317-325, 2019.

[28] Y. Jiang, J. Wen, J. Bai, X. Jia, and Z. Hu, Biodegradation of phenol at high initial concentration by Alcaligenes faecalis. J. Hazard. Mater, 147(1), 672676, 2007,.doi.org/10.1016/j.jhazmat.2007.05.031.

[29] Z. Aksu and F. Gönen, Biosorption of phenol by immobilized activated sludge in a continuous packed bed: prediction of breakthrough curves. Process Biochem., 39(5), 599-613, 2004.doi.org/ 10.1016/S0032-9592(03)00132-8. 